ISSN 0258-7122

Bangladesh J. Agril. Res. 37(3): 529-535, September 2012

\title{
EFFECT OF TILLAGE INTENSITY, FERTILIZER AND MANURE ON ROOT MASS DENSITY, SOIL PROPERTIES AND THEIR CORRELATION ON RICE (Oryza sativa L.) YIELD
}

\author{
M. M. SARKER ${ }^{1}$, M. A. MATIN ${ }^{2}$, M. G. HOSSAIN ${ }^{3}$ \\ M. M. R. SARKER ${ }^{4}$ AND M. S. HUDA ${ }^{5}$
}

\begin{abstract}
An experiment was carried out at the Bangladesh Agricultural University Farm, Mymensingh during the Aman season of 2008 to study the effect of tillage intensity, fertilizer and manure on the root mass density soil properties and their correlation on rice yield (BRRI dhan 41). The experiment was laid out in a split plot design with three replications. The treatments were three tillage operations as factor $\mathrm{A}$ : one passing $\left(\mathrm{P}_{1}\right)$, two passing $\left(\mathrm{P}_{2}\right)$, and three passing $\left(\mathrm{P}_{3}\right)$ of a power tiller and four fertilizer and manure treatments as factor $\mathrm{B}$ : recommended dose of fertilizers $\left(\mathrm{FM}_{0}\right), 50 \%$ of $\mathrm{N}$ plus rest of recommended dose of fertilizers + cowdung @ 5 t/ha $\left(\mathrm{FM}_{1}\right), 50 \%$ of $\mathrm{N}$ plus rest of recommended dose of fertilizers + rice straw @ $5 \mathrm{t} / \mathrm{ha}\left(\mathrm{FM}_{2}\right)$ and 50\% of N plus rest of recommended dose of fertilizer + cowdung @2.5 t/ha plus rice straw @ $2.5 \mathrm{t} / \mathrm{ha}\left(\mathrm{FM}_{3}\right)$. The highest and the lowest bulk densities were found in $\mathrm{P}_{1} \mathrm{FM}_{0}$ and $\mathrm{P}_{3} \mathrm{FM}_{2}$ treatments, respectively. The maximum soil moisture content and air filled porosity were obtained in $\mathrm{P}_{3} \mathrm{FM}_{1}$ treatment, whereas $\mathrm{P}_{1} \mathrm{FM}_{0}$ demonstrated the lowest soil moisture content. The maximum $\left(8.09 \mathrm{mg} \mathrm{cm}^{-3}\right)$ and minimum $\left(1.63 \mathrm{mg} \mathrm{cm}^{-3}\right)$ root mass densities were observed in $\mathrm{P}_{3}\left(10 \mathrm{~cm}\right.$ depth) and $\mathrm{P}_{1}$ (10-20 cm depth) treatments, respectively. The highest grain yield was recorded in $\mathrm{P}_{3} \mathrm{FM}_{0}$ treatment. Root mass density was positively correlated with soil moisture content and grain yield, but negatively with bulk density.
\end{abstract}

Keywords: Tillage, fertilizer, manure, correlation, yield.

\section{Introduction}

Rice is the most important food crop of Asia and it contributes about 92\% of the world rice harvest (IRRI, 1995). It is the major food crop of Bangladesh. The agro-climatological condition of Bangladesh is favourable for its cultivation all the year round. The per hectare yield of this crop is low in Bangladesh due to declining soil fertility and lack of proper tillage practices. Use of chemical fertilizers is an essential component of modern farming and about $50 \%$ of the world's crop production can be attributed to fertilizer use (Pradhan, 1992). But sustainable production of crops can not be maintained by using only chemical fertilizers, and similarly it is not possible to obtain higher crop yield by using

\footnotetext{
${ }^{1}$ Assistant Director, Ministry of Communication, Bangladesh Bridge Authority, Dhaka, ${ }^{2}$ Professor, Dept. of Soil Science, Bangladesh Agricultural University (BAU), Mymensingh, ${ }^{3,4,5}$ Scientific Officer, Bangladesh Agricultural Research Institute (BARI), Gazipur-1701, Bangladesh.
} 
organic manure alone (Rose et al., 2001). Organic manure acts as a buffer medium for making favourable environments by improving soil physical, chemical and microbial properties. Tillage practices suppress weeds, destroy insects' host, incorporates organic matter into the soil and alter the aggregates of size distribution. By altering the aggregates of size distribution, tillage also affects the physical and chemical properties of the soil, which in turn affects plant growth (Dexter, 1999) by controlling air and water movement and to a certain extent, enhance nutrient supply. Tillage operation also influences soil physical properties, water conservation, root growth, and crop yield. Zero tillage is not suitable for crop production, though it resists soil erosion, conserves moisture and reduces energy, because the roots of crop plants may not be able to move easily to deep soil to absorb adequate nutrient required for its better growth and yield. Therefore, the study was conducted to evaluate the effect of tillage operations, fertilizer and manure on the root mass density, soil properties and yield of rice.

\section{Materials and Method}

The experiment was conducted at the Bangladesh Agricultural University Farm during the Aman (Kharif-2) season of 2008. The experimental field belongs to the "Old Brahmaputra Floodplain" agroecological zone (AEZ-9). The land was first opened on 28 July 2008 with the help of a power tiller and it was further ploughed on 3 August 2008. Every ploughing was followed by laddering to have a good tilth. High yielding T.Aman variety BRRI dhan-41 was used as the test crop. The experiment was laid out in a split plot design with three replications. There were two sets of treatments viz. (A) three tillage treatments in main plot, namely $\mathrm{P}_{1}=$ One passing, $\mathrm{P}_{2}=$ two passings and $\mathrm{P}_{3}=$ three passings of a power tiller $\left(\mathrm{P}_{3}\right)$, and (B) fertilizer and manuring treatments in sub-plots, namely (a) recommended dose of fertilizer $\left(\mathrm{FM}_{0}\right)$, (b) $50 \%$ of $\mathrm{N}$ plus rest of recommended dose of fertilizers + cowdung @ 5 t/ha $\left(\mathrm{FM}_{1}\right)$, (c) $50 \%$ of $\mathrm{N}$ plus rest of recommended dose of fertilizers + rice straw @ $5 \mathrm{t} / \mathrm{ha}\left(\mathrm{FM}_{2}\right)$, and (d) 50\% of N plus rest of recommended dose of fertilizers + cowdung @ 2.5t/ha + rice straw @ $2.5 \mathrm{t} / \mathrm{ha}\left(\mathrm{FM}_{3}\right)$. The unit plot size was $4.0 \mathrm{~m}$ x $2.5 \mathrm{~m}$, plot to plot spacing was $0.5 \mathrm{~m}$ and block to block was $1 \mathrm{~m}$. The cowdung and the rice straw were applied after the first tillage operation and incorporated into the soil thoroughly. The land was fertilized by applying N, P, K, S, and Zn fertilizer as per Fertilizer Recommendation Guide (BARC, 2005). Data were recorded from five randomly selected samples of each treatment. Root mass density was measured at the maximum vegetative stage using auger like sampler of $7 \mathrm{~cm}$ in diameter as recommended by Schuurman and Goodevregen (1971). Data were statistically analyzed using MSTAT-C computer program (Gomez and Gomez, 1984). 


\section{Results and Discussion}

Effects of tillage intensity, fertilizer and manure on soil physical properties and root mass density

Root mass density was significantly influenced by tillage intensity (Table 1). The maximum root mass density of $8.09 \mathrm{mg} \mathrm{cm}^{-3}$ was recorded under $\mathrm{P}_{3}$ tillage treatment at surface soil $(0-10 \mathrm{~cm})$ depth, which was statistically different from the other treatments. The minimum value $\left(1.63 \mathrm{mg} \mathrm{cm}^{-3}\right)$ was found in $\mathrm{P}_{1}$ tillage treatment at $10-20 \mathrm{~cm}$ soil depth (Table 2). The result of this study is in agreement with the observation made by Hassan et al. (2005) and Khan et al. (1997). The rice root penetrated into the deeper layer under $P_{3}$ treatment and uptook more nutrients from different soil depths that influenced growth and development of rice. As a result, roots became thicker and increased root mass density. On the other hand, roots could not grow sufficiently under $\mathrm{P}_{1}$ treatment. Root mass density has drastically reduced with soil depth. The decline in root mass density was associated with the increase in bulk density (Table 2). Root proliferation was obstructed by compact layers in the soil profile, as reported by Parker and Lear (1996) and Singh and Singh (1996).

Table 1. Analysis of variance for soil physical properties, root mass density and yield of rice as influenced by tillage intensity, fertilizer and manuring.

\begin{tabular}{|c|c|c|c|c|c|c|c|}
\hline \multirow{3}{*}{$\begin{array}{l}\text { Source of } \\
\text { variation }\end{array}$} & \multicolumn{7}{|c|}{ Mean Square } \\
\hline & \multirow{2}{*}{$\begin{array}{c}\text { Soil } \\
\text { Moisture } \\
(\%)\end{array}$} & \multirow{2}{*}{$\begin{array}{c}\text { Bulk } \\
\text { density } \\
\left(\mathrm{g} \mathrm{cm}^{-3}\right)\end{array}$} & \multirow{2}{*}{$\begin{array}{c}\text { Air filled } \\
\text { Porosity } \\
\text { (\%) }\end{array}$} & \multicolumn{2}{|c|}{$\begin{array}{l}\text { Root Mass Density } \\
\qquad\left(\mathrm{mg} \mathrm{cm}^{-3}\right)\end{array}$} & \multirow[t]{2}{*}{$\begin{array}{l}\text { Yield } \\
\text { (t/ha) }\end{array}$} & \multirow{2}{*}{$\begin{array}{l}\text { Straw } \\
\text { yield } \\
\text { (t/ha) }\end{array}$} \\
\hline & & & & $0-10 \mathrm{~cm}$ & $10-20 \mathrm{~cm}$ & & \\
\hline Factor A & $87.457 * *$ & $0.313^{* *}$ & $12.835^{* *}$ & $8.808^{* *}$ & $1.715^{* *}$ & $2.217^{* *}$ & $0.884^{* *}$ \\
\hline Error & 2.104 & 0.002 & 0.849 & 0.004 & 0.257 & 0.037 & 0.102 \\
\hline Factor B & $107.539 * *$ & $0.197^{* *}$ & $24.172 * *$ & $2.14^{* *}$ & $1.96^{* *}$ & $1.782^{* *}$ & $1.069^{* *}$ \\
\hline$A B$ & $70.859 * *$ & $0.094 * *$ & $2.974^{* *}$ & $0.453^{* *}$ & $0.86^{* *}$ & 0.135 & $0.347^{* *}$ \\
\hline Error & 5.178 & 0.003 & 0.265 & 0.054 & 0.18 & 0.025 & 0.062 \\
\hline
\end{tabular}

** Significant at $1 \%$ level of probability, Factor A=Tillage operations, Factor B=

Fertilizer and manure treatments

Fertilizer and manure treatments had highly significant effect on root mass density. The highest root mass density $\left(7.82 \mathrm{mg} \mathrm{cm}^{-3}\right)$ was measured in the $\mathrm{FM}_{\mathrm{O}}$ treatment at $0-10 \mathrm{~cm}$ soil depth, which was different from other treatments. The lowest root mass density $\left(1.66 \mathrm{mg} \mathrm{cm}^{-3}\right)$ was recorded in the $\mathrm{FM}_{2}$ treatment at 10$20 \mathrm{~cm}$ soil depth (Table 2).

The interaction effect of tillage and fertilizer were also significant. The highest value of root mass density $\left(9.23 \mathrm{mg} \mathrm{cm}^{-3}\right)$ was observed in $\mathrm{P}_{3} \mathrm{FM}_{0}$ 
treatment and the lowest at $0-10 \mathrm{~cm}$ soil depth $\left(1.35 \mathrm{mg} \mathrm{cm}^{-3}\right)$ was found at $\mathrm{P}_{1} \mathrm{FM}_{3}$ treatment at 10-20 $\mathrm{cm}$ soil depth (Table 2).

\section{Effects of tillage intensity, fertilizer and manure on yield of rice grain yield}

Tillage intensity and fertilizer and manure significantly influence on the grain yield of BRRI dhan-41 (Table 1). The highest grain yield (4.85 t/ha) was found in $\mathrm{P}_{3}$ treatment while $\mathrm{P}_{1}$ recorded the lowest yield (3.78 t/ha) (Table 2). This finding was supported by Ranjan et al. (2006), Matin and Uddin (1994) and Ardell et al. (2001). In case of fertilizer and manuring, the highest yield (4.74 t/ha) was recorded with $\mathrm{FM}_{0}$ treatment.

Table 2. Effects of tillage intensity, fertilizer and manuring and their interactions on soil physical properties, root mass density and yield of rice.

\begin{tabular}{|c|c|c|c|c|c|c|c|}
\hline \multirow[t]{2}{*}{ Treatment } & \multirow{2}{*}{$\begin{array}{c}\text { Soil } \\
\text { moisture } \\
(\%)\end{array}$} & \multirow{2}{*}{$\begin{array}{c}\text { Bulk } \\
\text { density } \\
\left(\mathrm{g} \mathrm{cm}^{-3}\right)\end{array}$} & \multirow{2}{*}{$\begin{array}{c}\text { Air filled } \\
\text { porosity } \\
(\%)\end{array}$} & \multicolumn{2}{|c|}{$\begin{array}{l}\text { Root mass density } \\
\qquad\left(\mathrm{mg} \mathrm{cm}^{-3}\right)\end{array}$} & \multirow{2}{*}{$\begin{array}{l}\text { Grain } \\
\text { yield } \\
\text { (t/ha) }\end{array}$} & \multirow{2}{*}{$\begin{array}{l}\text { Straw } \\
\text { yield } \\
\text { (t/ha) }\end{array}$} \\
\hline & & & & $(0-10) \mathrm{cm}$ & $(10-20) \mathrm{cm}$ & & \\
\hline \multicolumn{8}{|l|}{ Tillage } \\
\hline $\mathrm{P}_{1}$ & $47.80 \mathrm{~b}$ & 1.28a & $12.09 \mathrm{~b}$ & 6.41c & $1.63 b$ & $3.78 \mathrm{~b}$ & $6.00 \mathrm{~b}$ \\
\hline $\mathrm{P}_{2}$ & $49.44 \mathrm{~b}$ & $1.17 \mathrm{~b}$ & $12.33 \mathrm{~b}$ & $6.95 \mathrm{~b}$ & $2.24 a$ & $3.91 \mathrm{~b}$ & $6.10 \mathrm{~b}$ \\
\hline $\mathrm{P}_{3}$ & $53.08 \mathrm{a}$ & $0.96 \mathrm{c}$ & 13.99a & $8.09 a$ & 2.33a & $4.58 \mathrm{a}$ & $6.52 \mathrm{a}$ \\
\hline \multicolumn{8}{|c|}{ Fertilizer - Manure treatments } \\
\hline $\mathrm{FM}_{0}$ & $45.53 c$ & 1.33a & $11.03 d$ & 7.82a & $2.74 a$ & 4.74a & $6.01 \mathrm{bc}$ \\
\hline $\mathrm{FM}_{1}$ & $53.63 a$ & $1.17 \mathrm{~b}$ & $14.72 \mathrm{a}$ & $6.88 c$ & $1.98 \mathrm{~b}$ & $3.77 \mathrm{c}$ & $5.92 \mathrm{c}$ \\
\hline $\mathrm{FM}_{2}$ & 51.63ab & $0.99 \mathrm{~d}$ & $13.52 \mathrm{~b}$ & $7.17 \mathrm{~b}$ & $1.66 \mathrm{~b}$ & $3.85 \mathrm{c}$ & $6.22 \mathrm{~b}$ \\
\hline $\mathrm{FM}_{3}$ & $49.64 \mathrm{~b}$ & $1.06 \mathrm{c}$ & $11.95 \mathrm{c}$ & $6.71 \mathrm{c}$ & $1.89 \mathrm{~b}$ & $4.01 \mathrm{~b}$ & $6.69 \mathrm{a}$ \\
\hline LSD0.05 & 2.403 & 0.412 & 0.612 & 0.5487 & 0.1414 & 0.1566 & 0.246 \\
\hline \multicolumn{8}{|c|}{ Tillage $\times$ Fertilizer - Manure treatments } \\
\hline $\mathrm{P}_{1} \mathrm{FM}_{0}$ & $40.64 \mathrm{e}$ & $1.46 \mathrm{a}$ & $10.14 \mathrm{~g}$ & 6.79de & 2.05b-e & $4.48 \mathrm{~b}$ & $5.91 \mathrm{bc}$ \\
\hline $\mathrm{P}_{1} \mathrm{FM}_{1}$ & 51.74abc & $1.36 \mathrm{~b}$ & 14.31bc & 6.43efg & 1.53de & 3.59de & $5.92 \mathrm{bc}$ \\
\hline $\mathrm{P}_{1} \mathrm{FM}_{2}$ & $50.65 b c$ & $1.12 \mathrm{c}$ & 13.7bcd & $6.28 f g$ & 1.6de & $3.34 \mathrm{e}$ & $6.21 \mathrm{~b}$ \\
\hline $\mathrm{P}_{1} \mathrm{FM}_{3}$ & 48.19cd & $1.18 \mathrm{c}$ & $10.22 \mathrm{~g}$ & $6.13 \mathrm{~g}$ & $1.35 \mathrm{e}$ & $3.71 \mathrm{~d}$ & $6.37 \mathrm{~b}$ \\
\hline $\mathrm{P}_{2} \mathrm{FM}_{0}$ & 44.61d & $1.39 a b$ & $10.29 \mathrm{~g}$ & $7.44 c$ & 2.83ab & 4.77ab & $6.03 \mathrm{bc}$ \\
\hline $\mathrm{P}_{2} \mathrm{FM}_{1}$ & 53.75ab & $1.19 \mathrm{c}$ & 14.5dab & $6.90 \mathrm{~d}$ & $2.53 b c$ & 3.56de & $5.69 c$ \\
\hline $\mathrm{P}_{2} \mathrm{FM}_{2}$ & 50.93bc & $1.01 \mathrm{de}$ & 13.34de & 6.58de & 1.58de & 3.60de & $6.15 b c$ \\
\hline $\mathrm{P}_{2} \mathrm{FM}_{3}$ & 48.19cd & $1.10 \mathrm{~cd}$ & $11.18 \mathrm{f}$ & 6.59def & 2.02cde & $3.74 d$ & $6.14 \mathrm{bc}$ \\
\hline $\mathrm{P}_{3} \mathrm{FM}_{0}$ & 51.36abc & $1.15 c$ & $12.65 \mathrm{e}$ & $9.23 a$ & 3.33a & 4.98a & $6.07 \mathrm{bc}$ \\
\hline $\mathrm{P}_{3} \mathrm{FM}_{1}$ & $55.4 \mathrm{a}$ & $0.95 \mathrm{ef}$ & $15.34 a$ & $7.32 \mathrm{c}$ & 1.87cde & $4.16 \mathrm{c}$ & $6.15 b c$ \\
\hline $\mathrm{P}_{3} \mathrm{FM}_{2}$ & 53.3ab & $0.85 \mathrm{~g}$ & 13.51cde & $8.37 \mathrm{~b}$ & 1.8cde & $4.61 \mathrm{~b}$ & $6.28 \mathrm{~b}$ \\
\hline $\mathrm{P}_{3} \mathrm{FM}_{3}$ & $52.26 \mathrm{abc}$ & $0.9 \mathrm{fg}$ & $14.45 \mathrm{abc}$ & $7.42 \mathrm{c}$ & $2.31 \mathrm{bcd}$ & $4.58 \mathrm{~b}$ & $7.56 a$ \\
\hline LSD0.05 & 3.903 & 0.094 & 0.883 & 0.398 & 0.727 & 0.4736 & 0.427 \\
\hline
\end{tabular}


Same letter(s) in a column does not differ significantly at 5\% level of probability; $\mathrm{P}_{1}=$ One passing, $\mathrm{P}_{2}=$ two passings and $\mathrm{P}_{3}=$ three passings of a power tiller; $\mathrm{FM}_{0}=$ Recommended dose of fertilizer, $\mathrm{FM}_{1}=50 \%$ of $\mathrm{N}$ plus rest of recommended dose of fertilizers + cowdung @ $5 \mathrm{t} / \mathrm{ha}, \mathrm{FM}_{2}=50 \%$ of $\mathrm{N}$ plus rest of recommended dose of fertilizers + rice straw @ $5 \mathrm{t} / \mathrm{ha}$ and $\mathrm{FM}_{3}=50 \%$ of N plus rest of recommended dose of fertilizers + cowdung @ 2.5t/ha + rice straw @ $2.5 \mathrm{t} / \mathrm{ha}$.

The lowest grain yield of $3.77 \mathrm{t} / \mathrm{ha}$ was recorded in $\mathrm{FM}_{1}$ treatment. The interaction effects of tillage, fertilizer, and manuring on yield was also significant (Table 1). The highest yield of $4.98 \mathrm{t} /$ ha was found in $\mathrm{P}_{3} \mathrm{FM}_{\mathrm{O}}$ treatment, and the lowest (3.34 t/ha) was found in $\mathrm{P}_{1} \mathrm{FM}_{1}$ (Table 2).

\section{Straw yield}

Tillage intensity significantly influenced the straw yield of BRRI dhan-4l (Table 1). The highest straw yield of $6.52 \mathrm{t} / \mathrm{ha}$ was recorded in $\mathrm{P}_{3}$ treatment (Table 2) where loose soil permited the penetration of the roots into the deeper layer for up take of water and mineral nutrients. Positive physiological and metabolic activities of rice were probably influenced by tillage operation and thus grain and straw yields were increased. Application of fertilizer and manure showed significant effect on the straw yield. The highest straw yield of $6.69 \mathrm{t} / \mathrm{ha}$ was recorded in $\mathrm{FM}_{3}$ treatment and the lowest yield (5.92 t/ha) in $\mathrm{FM}_{1}$ (Table 2). The interaction effect of tillage, fertilizer and manuring showed significant results on straw yield. The highest straw yield (7.56 t/ha) was observed in the $\mathrm{P}_{3} \mathrm{FM}_{3}$ treatment combination. The lowest straw yield (5.69 t/ha) was obtained in $\mathrm{P}_{2} \mathrm{FM}_{2}$ treatment (Table 2).

\section{Correlation among root mass density, soil properties and yield of rice}

Although not significant, root mass density was positively correlated $(r=0.284)$ with soil moisture content. (Fig. 1). A weak negative relationship $(r=-0.272)$ was found between bulk density and root mass density. Rice yield depended largely on root mass density. Grain yield has a positive relationship with root mass density $(\mathrm{r}=0.750 ; \mathrm{P}<0.01)$ (Fig. 3). Positive relationship indicated that increase of grain yield was dependent on increase of root mass density. On the other hand, grain yield had a negative relationship with bulk density which indicated that grain yield would decrease with the increase of bulk density. Because high bulk density restricted root growth that affected the yield contributing characters of rice. 


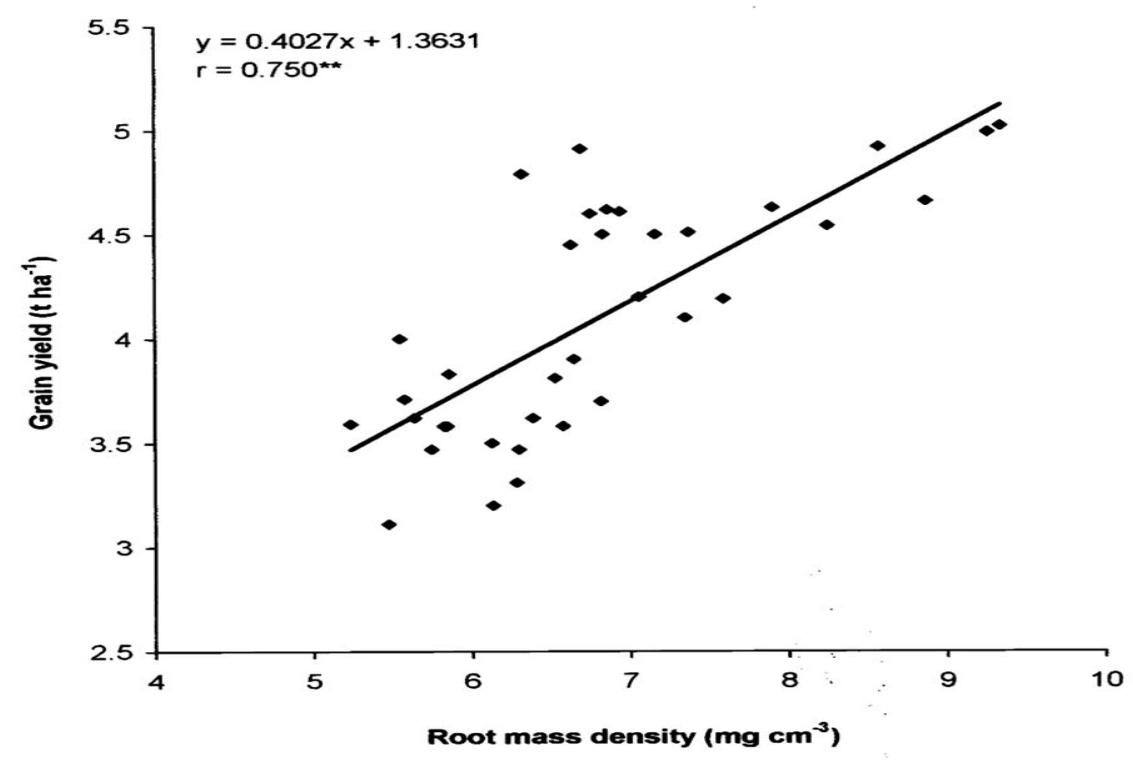

Fig. 3. Correlation between grain yield and root mass density.

\section{Conclusion}

Root mass density was positively correlated with soil moisture content and grain yield of rice, but had a negative relationship with bulk density. Regarding tillage treatment and fertilizer and manuring, the treatment combination $\mathrm{P}_{3} \mathrm{FM}_{0}$ (three passing of a power tiller with recommended dose of fertilizer) was most suitable for both root mass density and yield of rice.

\section{References}

Ardell, D., A.L. Halvorson, J.N. Black, S.D. Krupingley, B.J. Merril, Wienhold and K.L. Tonaka. 2001. Spring wheat response to tillage system and nitrogen fertilization within crop tallow system. Agron. J. 92:151.

BARC(Bangladesh Agricultural Research Council). 2005. Fertilizer Recommendation Guide. Soil pub. no. 41, Bangladesh Agril. Res. Council, Farmgate, Dhaka

Dexter, A. R. 1999. Soil mechanics relation to tillage implements and root penetration in low land soils. In: Soil physics and rice. Int. los Banos. Philippines. Pp. 261-275.

Gomez, K.A. and A.A. Gomez. 1984. Statistical Procedures for Agricultural Research $2^{\text {nd }}$ Edn. IRRI., Los Banos, Languna, The Philippines. Pp. 62-74.

Hassan, A.E., Y. Kitamura, E.S. Ahmed, G. Samir, and M. Irshad. 2005. Effect of irrigation schedules and tillage system on rice productivity and soil physical characteristics: a case study in the North Nile Delta. Egypt. Vol-A. Improving water and land management for increasing efficiency in irrigated agriculture. Pp. 1-19. 
IRRI (International Rice Research Institute). 1995. Effect of rice land drainage and soybean tillage treatments on rainfed, soybean grown after wetland rice. IRRI Annual Report for 1979. Loss Bons, Philippines, pp. 285-287.

Khan, M.S., T. H. Khan, A.M.S. Ullah, and R.R. Shaha. 1997. Effects of alternate tillage practices on rooting characteristics of wheat under rice wheat cropping sequence. Japanese J.Tropical Agric. 45(2):126-132

Matin, M. A. and M.S. Uddin. 1994. Effect of two tillage systems on soil physical properties, root growth and the yield of rice and maize. Pak. J. Sci. Industry. Res. 37(5): 201-203.

Parker, M.M. and D.H.V. Lear. 1996. Soil heterogeneity and Root distribution of mature loblolly pine stands in piedmont soil. Soil Sci.Soc.Am.J. 60(6):19-20

Pradhan. S. B. 1992. Status of fertilizers use in developing countries of Asia and the Pacific Region In: Proc. Regional FADINAP Seminar. Chiang Ma. Thiland Pp-47.

Ranjan, B., R.D. Singh, S. Chandra, S. Kundu and H.S. Gupta. 2006. Effect of tillage and irrigation on yield and properties under rice (Oryza sativa), wheat (Triticum aestivum) system on sandy clay loam soil of Uttaranchal. Indian. J. Agric. Sci. 76(7): 405-409.

Rose, E., B. Rarthes, C. Martias, H. Tiessen and P. L. G. Vledk. 2001. Organic matter management for soil conservation and productivity restoration in Abrica, Special assure Managing organic matter in tropical soils; scope and limitations. Proceeding of a workshop organized by the Centre of Development Research Univ. Bonn. Germany. 7-10 June 1999. Nutri. Cycling Agro-ecosystems 61(12): 159-170.

Schuurman, A. and B. goodewaagen. 1971. Methods of root studies under conditions, Man. Irri. Agron., Pp. 294-312.

Singh, P.K. and Singh. 1996. Effect of reduced tillage on soil properties, root growth and grain yield in rice -wheat system. Indian J. Agrl. Res. 30(8):179-185. 